\title{
Japan takes US role model
}

\section{Tokyo}

AN influential society of Japanese academics and industrialists recommended on Monday that the Japanese government should form an equivalent of the US Office of Technology Assessment (OTA) to oversee science and technology policy and in particular large-scale international research projects, such as Japan's participation in the US space station and global environment research. But the proposal is bound to meet strong resistance in certain government circles.

The Japan Society of Technology, which made the proposal in a report entitled A proposal concerning technology and human welfare: toward building a harmonious global society, consists of nearly 70 senior academics and industrialists, including Haruo Yamaguchi, chairman of Nippon Telegraph and Telephone Corporation, Michio Okamoto, former member of the Council of Science and Technology, Japan's leading science policy-making body which is chaired by the prime minister, and Jiro Kondo, president of the Science Council of Japan (JSC), the leading academic advisory council of the government. An ad hoc committee of the society took two years and about 20 meetings to compile the report, which has been submitted to Prime Minister Toshiki Kaifu and to heads of all science-related ministries and agencies.

Kondo, who chaired the ad hoc committee, points to the US request for Japan to participate in the Superconducting Super Collider (SSC) project as an example of the sort of global research issues the proposed Japanese OTA would tackle. Since the US Department of Energy officially invited Japan to join the SSC project in June, the Japanese government has been paralysed by the inability of any of the government ministries and agencies involved to take a lead and reply to the US request.

What is needed, says Kondo, is a public organization that includes scientists and specialists in the humanities and social sciences to assess the social as well as the scientific and technological value of such projects. But the government has so far made no attempt to ask academics what they think of the SSC, he says. In contrast, he cites Japan's Human Frontier Science Program as an example of a successful international project that included significant input from Japanese academics.

Kondo says the proposed technology assessment office would also look at domestic government research projects and where necessary recommend termination. He gives the nuclear-powered ship Mutsu as an example - after more than 20 years and an expenditure of about $\$ 1,000$ million, Mutsu has spent only a few days at sea and will be scrapped next year.

But the proposal is intended to be much more than just a recommendation to form a domestic Japanese OTA. The society's ultimate aim is the establishment of an international body like the United Nations that would oversee global technology projects and Overseas Development Aid in an attempt to ensure that technology benefits all mankind. But before that lofty goal can be achieved, Japan will have to put its own house in order.

Although many people in Japanese government and academic institutions have long agreed that there is an urgent need for an independent watchdog to monitor government science and technology policy, all attempts to form such an organization have failed. The JSC, when established 40 years ago, was supposed to fill such a role. But after about 20 years, the ruling conservative Liberal Democratic Party (LDP) became convinced that the council was run by "a nest of communists", says Kondo, because it often disagreed with government policy. And in 1985 the system of election of council members was restructured to allow the prime minister to screen all candidates.

The Science and Technology Council chaired by the prime minister is now the principal organization for setting policy. But the council is closely related to the Science and Technology Agency, in which its office is located, and as a result its independence is open to question.

Kondo believes that JSC could organize the proposed assessment office if it were given a budget. But the JSC budget has been frozen since 1985 and although relations have improved with the LDP, there are still some members of the ruling party who are suspicious of the council's links with communist countries.

Tomorrow (14 December), an advisory council of the Science and Technology Council is expected to publish a separate series of recommendations for dealing with global science and technology issues. And with two reports in one week, debate of this controversial issue is bound to heat up.

David Swinbanks

\section{Public funds for POST?}

\section{London \& Munich}

THE UK Parliamentary Office of Science and Technology (POST), set up in April 1989 to inform Members of Parliament (MPs) on scientific issues, may win support from public funds following the change in prime minister

After former prime minister Margaret Thatcher refused to provide any public money, POST's founder, the Conservative MP Sir Ian Lloyd, turned to companies and charitable foundations for donations. A number of MPs (ironically, including Thatcher herself) have also provided smaller sums from their own pockets. But Lloyd says he was able to press POST's claim for public funding with the three

\section{ACADEMIC FREEDOM}

\section{Clampdown continues}

\section{London}

Moneim Attia, the Sudanese environmental physiologist imprisoned without trial since January (see Nature 348, 5; 1 November 1990), has now been released. But Alex de Waal, from the human rights pressure group Africa Watch, says that the abuse of academic freedom by the governing Sudanese revolutionary council continues unabated. Most political detainees are released after several weeks or months, he says, and a number have since been rearrested. About 130 university lecturers have been dismissed in the past three weeks, apparently on political or ideological grounds. candidates to succeed Thatcher, as they vied for the support of Conservative MPs in the party's leadership election. The new prime minister John Major is said to have an open mind on POST's funding.

POST expects to spend about $£ 150,000$ in the coming year, producing ten briefing notes for MPs. Three reports, in the style of those from the US Office of Technology Assesment (OTA), on computing in schools, research in the National Health Service and the balance between civil and defence research spending, are also being prepared. Lloyd says that POST is "quite unashamedly modelled on the OTA", but with a permanent staff of only four, POST's activities are severely limited. Unlike POST, however, both OTA and the science policy division of the Congressional Research Service (which provides a similar service to POST's briefing notes) are publicly funded.

Other European countries fund similar, if smaller, organizations, says Michael Norton, POST's director. The German parliament set up a Technology Assessment Office last June, giving it a budget of over DM 2.5 million (about $£ 870,000$ ) a year, for a three-year trial period.

Lloyd says the first step is to get public funds for POST to match private donations. Changes to the mechanism of parliament happen very slowly, but he hopes for a "positive development" before the next general election.

Peter Aldhous \& Steven DIckman 